\title{
TAX LAW: THIRD PARTY AS PAYER OF INCOME FROM DEPENDENT ACTIVITY ${ }^{1}$
}

\author{
Jana Tepperová \& Lucie Rytířová ${ }^{2}$
}

\section{Department of Public Finance, The University of Economics, Prague, Czech Republic \& Ministry of Finance of the Czech Republic email: jana.tepperova@vse.cz, Rytirova.L@seznam.cz}

TEPPEROVÁ, Jana; RYTÍŘOVÁ, Lucie. Tax Law: Third Party as Payer of Income from Dependent Activity. International and Comparative Law Review, 2013, Vol. 13., No. 1, pp. 147-161. DOI: 10.1515/iclr-2016-0065.

\begin{abstract}
Employment related income paid by a third party (non-employer) has its specific tax treatment. In the Czech Republic, a different approach applies for calculation of personal income tax and obligatory insurance contributions from this income. With the preparation of the Single Collection Point (unifying the collection of personal income tax and obligatory insurance contributions), the question arises whether it is possible to set up unified treatment of this income for all obligatory payments. We provide detailed analyses of this topic from the point of view of the Czech legislation and comparison with selected countries. Further we follow with the discussion of problematic issues in unified treatment for all obligatory payments from this income; such as discrimination and complicated administration. We conclude that even if the national legislation for all obligatory payments from this income would not differ, there will still be different treatment due to specific international regulations.
\end{abstract}

Keywords: employment income, payroll taxation, social security contributions, single collection point

\section{Introduction}

Taxation of employment income (income from dependent activity) is within tax systems quite separate field and the corresponding tax liability is usually higher than of income from other activities. A key role in this context play con-

1 The paper was produced as one of the outputs from the research project of the Faculty of Finance and Accounting, University of Economics in Prague, which is realized within the institutional support of University of Economics in Prague No. IP100040.

The article takes into consideration legislation effective in 2013. New legislation effective since January 2014 has changed the situation, which will be subject to further analysis.

2 Jana Tepperová is a Senior Lecturer at Department of Public Finance, The University of Economics, Prague, Czech Republic. Email: jana.tepperova@vse.cz.

Lucie Rytírová works at the Ministry of Finance of the Czech Republic. Email: Rytirova.L@ seznam.cz. 
tributions on obligatory insurance. Therefore, it is important to clearly state what the income from employment is.

The relevant Czech legislation specifies the income from dependent activity clearly. Due to this definition, there is a consensus on the types of the taxable employment income; it includes both regular and irregular income paid out in cash or in a non-monetary form including also all kinds of discounts and noncash benefits. This broad definition of taxable income is also accepted for the purposes of contributions to obligatory insurance.

However, there is not so wide consensus on the specification of payers of the employment income in the Czech legislation. Income related to employment will be subject to the personal income tax from dependent activity regardless who the payer of the income is. The specifics of insurance compared to income tax complicate the application of the same approach for calculation of the contributions to obligatory insurance. This inconsistency can be used for tax optimization to minimize the cost of employment benefits.

Typical situations - when the employment income is paid by someone else than the legal employer (a third party) - are stock option plans, or different kinds of employment benefits, such as provision of wellness or sport activities to employees. Often the payment of employment income is a part of a special employment structure, e.g. hire out of labour.

Based on real practical examples we define a general remuneration structure. We analyze in detail this structure according to the Czech legislation and discuss possible approaches to the tax consequences of the structure. This discussion brings us to question principal issues such as what is an employment-related income, who should bear the social security expenses, how far should we go with the assimilation of facts in social security coordination etc.

There is not much literature on the concrete examples/analyses of the situation when the income related to employment is paid directly by a third party. The technicalities for the purposes of the personal income tax were analyzed within the Coordinating Committee of The Chamber of Tax Advisers and the Ministry of Finance in $2007^{3}$ (discussed further). The Chamber of Tax Advisers also provoked a discussion on this issue with the Ministry of Health Insurance which leaded to an official statement issued in $2008 .{ }^{4}$ Brief information on this issue presents Červinka in practical information about changes in definition of employee and employer in $2008 .^{5}$

3 See the conclusions of the negotiations of the Coordinating Committee of the Ministry of Finance and the Chamber of Tax Advisers No. 730/08.10.03

4 See the standpoint No. MZDR 20764/2009/DZP of the Ministry of Health Insurance dated 18 May 2009.

5 See Červinka, T. (2008): Mezinárodní pronájem pracovní síly a odvod pojistného na zdravotní pojištění. Finanční, daňový a účetní bulletin, III/08, p. 46-48. 
As for the discussion on broader consequences of the case, the theoretical literature is more developed. In further discussion we use mainly literature related to assimilation of facts. ${ }^{6}$

The paper is structured as follows. First we provide a detailed analysis of taxation of employment-related income in the Czech Republic with the specification of the problematic questions. Further we present the tax treatment of the employment-related income paid by a third party in selected countries, followed by the discussion of the related basic principles. We close the paper with a short summary pointing out the main conclusions.

\section{Analysis for the Czech Republic}

A starting point for determination of treatment of an individual's income in the area of personal income tax, social security ${ }^{7}$ and health insurance contributions is specification of basic terms: an employment income, an employee and an employer. These definitions differ for each of these areas, as specified by the respective legislation.

Generally, employment income is the income which is paid to an employee by an employer, in relation to an employment activity. For certain implications, it is important for who is the employment activity performed: for the payer of the income, or for another entity. Other important criteria might be the existence of a formal relationship between the individual and the payer of the income.

For the income tax, social security and health insurance implications of the employment-related income provided by a third party, it is important whether the related costs are re-invoiced by the payer (a third party) to the legal employer, as discussed in detail below.

\subsection{Personal Income Tax}

The Act No. 586/1992 Coll., on Income Taxes (hereinafter "Income Taxes Act"), derives the specification of an employee and an employer from the definition of employment income. An employee is a receiver of an employment income; an employer is a payer of such income.

This definition of the employment income is very wide. It includes all income from the current, previous or future employment or similar relationship, in which the individual is subject to orders and instructions of the payer of the income. In addition, certain types of income are deemed to be employment

6 See e.g. Pennings F. (2010): European Social Security Law. Fifth edition, Intersentia, 2010; Koldinská, K. et al. (2012): Sociální zabezpečení osob migrujících mezi státy EU. C.H.Beck, 2012; Jorens, Y. - Overmeiren, F. (2009): General Principles of Coordination in Regulation. European Journal of Social Security, 11, 2009.

7 For the purposes of the Section 2 of the paper, we use the term social security as used by the Czech legislation, i.e. covering the pension, sickness and unemployment insurance. 
income even if there is no dependent relationship between the individual and the payer of the income, e.g. income for the activity of members of cooperatives, members of statutory boards, executives etc. ${ }^{8}$

For the personal income tax purposes, it is irrelevant whether the income is paid by an entity for which the individual performs a dependent activity, or from any other payer (a third party), if such income relates to a dependent activity performed for someone else.

Practical application of this definition means that employment income is anything which relates to a dependent activity (employment) and the payer of this income is considered an employer for the personal income tax purposes. Neither a legal relationship, nor a performance of activity for the payer is required.

The Income Taxes Act binds the obligation to pay the personal income tax on the moment when the income is actually paid out to an employee (to a bank account, in cash, as a non-monetary benefit etc.) or when it is accounted to an employee. Each income, to which an employee is entitled based on his employment activity (performed for the payer of the income, or for another entity) is considered an accounted income. The tax obligation for the personal income tax purposes then arises either when the income is paid to an employee, or when it is accounted to him, whichever comes first.

If the employer (i.e. the entity which pays out or accounts the employment income to the employee) is a registered payer of the personal income tax, he has to process the employment income through the payroll, i.e. withhold the Czech personal income tax from dependent activity from this income and transfer it to the Czech tax authority. The definition of a registered payer covers the following subjects: ${ }^{9}$

- an entity seated in the Czech Republic, which pays out or accounts the income,

- a Czech permanent establishment of an entity seated abroad, except for a permanent establishment created due to provision of services at the Czech territory and foreign embassies.

A special definition of an employer is stipulated for the situation of international hiring out of labour. ${ }^{10}$ In this case, the employer for the Czech payroll tax is deemed to be the Czech entity, at which the employees work (under its orders and instructions), even if they are legally employed by a foreign entity, which also pays them their remuneration. The Czech entity, the employer de facto (or economic employer), is then required to pay the Czech payroll tax from the individual's remuneration, even if it does not pay this remuneration directly to them but it is being invoiced by the foreign entity.

8 See Section 6 para 1 of the Act No. 586/1992 Coll., Act on Income Taxes, as amended.

9 See Section 38c of the Act No. 586/1992 Coll., Act on Income Taxes, as amended.9

10 See Section 6 para 2 of the Act No. 586/1992 Coll., Act on Income Taxes, as amended. 
The international hiring out of labour is a typical case when employment income is paid by an entity for which the individual does not perform any activity. Since the personal income tax treatment is specifically stipulated by the law in this case, there are no doubts who should pay the personal income tax. However, there might also be situations in which the related obligations are not clearly specified, e.g., when the individual works for one entity but receive the employment income from another entity, which does not have any relationship with the individual's employer (a third party). In such situation special tax treatment for international hire out of labour does not apply.

In case the costs of the employment income remain to be borne by the third party, no further steps need to be taken. On the other hand, if it decides to reinvoice these costs to the individual's employer (or the entity for which the individual performs his work), ${ }^{11}$ it might be questioned whether the obligation to process the income through the payroll lies only with the third party (the payer of the income), or with the individual's employer, or both. These doubts should be clarified by a recent standpoint of the General Financial Directorate, expressed in the Coordinating Committee with the Chamber of Tax Advisers. ${ }^{12}$

In situations when the payer of the employment income does not fulfill the conditions for a registered payer of the personal income tax (e.g., because it is an entity seated abroad), the individual has to include the income as the employment income (according to the Section 6 of the Income Taxes Act) in his annual Czech personal income tax return and pay the tax from it himself.

\subsection{Social security}

In the area of social security (i.e. pension insurance, sickness insurance and unemployment insurance), an income (as specified above for the personal income tax purposes, i.e. both monetary and non-monetary) related to an employment activity is subject to the social security contributions on condition that it is paid by an employer to an employee. However, definitions of these terms differ from the definitions used in the personal income tax area.

Currently, an employee for the social security purposes is defined by enlisting the respective categories of individuals. ${ }^{13}$ Anyone who is not specifically mentioned in this list is not considered an employee. They might participate at the Czech social security system as another category (e.g. a self-employed individual or a voluntary participant), or not participate at all.

11 E.g., based on the transfer pricing rules, requiring each related entity to bear the costs of an activity from which it benefits.

12 See the conclusions of the negotiations of the Coordinating Committee No. 393/20.02.13.

13 See Section 5 of the Act No. 187/2006 Coll., Act on Sickness Insurance, as amended. 
An employer is an entity which has the legal relationship with the employee. It might be seated in the Czech Republic, or in a country with which the Czech Republic has concluded an international social security agreement. ${ }^{14}$

Practically, the definition of an employee includes most of individuals who are considered employees for the personal income tax purposes. However, there is a significant difference with respect to income paid by a third party. In case there is no legal relationship between the individual and the payer of the income, they are not considered an employee and an employer for the social security purposes, even if the individual actually works for the payer. Consequently, the income paid to the individual by this entity is not considered an employment income for the social security purposes and there are no Czech social security contributions due from this income, regardless of treatment of this income from the personal income tax point of view.

According to the current rules, if an employee receives income related to his employment activity from an entity with which he does not have any legal relationship (a third party), such income is not subject to the Czech social security contributions. This applies even if the individual performs an employment activity for the payer of the income. The relationship between the two entities (e.g., a parent company and a subsidiary) is not relevant.

However, unlike in the personal income tax area, the social security treatment of such income differs if it is re-invoiced by the payer to the employer. The reason is that the assessment base for the Czech social security contributions equals to the accounted income, which according to the social security legislation includes all income which is provided to an employee by an employer in a monetary or non-monetary form, as a benefit or in any other way. ${ }^{15}$ This term in its official interpretation includes any income which an employer has in its accounting books accounted in the name of the employee, generally on a payroll sheet. Should the payer of the income, with which the employee does not have any legal relationship, recharge the costs of the income to the legal employer of the employee, the employer has to include this income to the payroll for the social security purposes.

Effective as of January 2014, the definitions for the social security purposes should be amended. ${ }^{16}$ The new definitions should be practically same as for the health insurance purposes as specified below. Although the draft amendment

14 Regulation (EC) No 883/2004 of the European Parliament and of the Council of 29 April 2004 on the coordination of social security systems; and Bilateral Agreements on Social Security, overview of the bilateral agreements is available at: http://www.mpsv.cz/cs/1275, [Access 26 April 2013].

15 See Section 5 para 1 of the Act No. 589/1992 Coll., on the Social Security Contributions and the Contribution to the State Unemployment Policy, as amended.

16 Proposal of the Act on the Amendment of Tax Legislation related to the Recodification of the Private Law and the Amendment of Other Legislation, No. 1004 
of the legislation still includes an enlisting overview of the employee's category, there should be a generalizing point covering all other individuals who perform dependent activity for which they receive income. There will still be a difference compared to the personal income tax treatment, since performance of an activity for the payer of the income will be required. Therefore, a third person paying income related to an employment activity performed by an individual for another entity will not be considered an employer for the Czech social security purposes and there will be no Czech social security contributions due from such income. This treatment stems from the purpose of the social security system, which is to compensate a drop out of income when an individual cannot perform the gainful activity (because of sickness, old-age etc.). When there is no activity done by the individual, he might continue receiving the income during his incapacity to work; there is thus nothing to be compensated for.

According to the proposed regulations, an income paid to an employee in relation to his employment activity by a third party, should thus still be exempt from the Czech social security contributions; ${ }^{17}$ the Czech social security contributions should only be extended to income from an entity with which the individual does not have a legal relationship, but for which he actually works. Different treatment of employment income re-invoiced to the employer of the individual, which applies currently, should be applicable as well, same as the irrelevance of the relationship between the entity which pays out the income and for which the employee works.

The only situation when the legal relationship is not required for the purposes of payment of the Czech social security contributions is the assignment structure of international hiring out of labour from a country with which the Czech Republic has not concluded any treaty on the social security. ${ }^{18}$ The legal employer, seated in such country, is called "a foreign employer". The Czech entity, at which the individuals perform their activity, is called "a contractual employer" and the individuals "contractual employees". The contractual employee's position differs slightly from a standard employee's position, since he participates at the Czech social security as of the first date of his activity in the Czech Republic only if he is not covered by a pension insurance in the country where his legal employer is seated. Otherwise, he participates only after 270 days of his activity in the Czech Republic, calculated in two consecutive years. Similar to the treatment of the international hiring out of labour in the area of the personal income tax, the contractual employer has the same obligations as a standard employer in the social security area. The income paid by the contractual employer to the contractual employee, both paid directly and through the foreign employer

17 This might be amended in the future, in relation to creation of the Single Collection Point, unifying the collection of the personal income tax, social security and health insurance contributions.

18 See Section 3 letter o) of the Act No. 187/2006 Coll., Sickness Insurance Act, as amended; this treatment does not apply to countries covered by the European social security coordination 
(invoiced to the contractual employer), is considered employment income which is subject to the Czech social security contributions.

\subsection{Health insurance}

The treatment of an income related to an employment activity in the health insurance area is similar to the social security area in the way that it has to be paid by an employer to an employee. Also this area defines these terms differently.

The definition of an employee for the health insurance purposes is closely related to its definition for the personal income tax purposes, i.e. as someone who receives income from employment. There are a few exemptions stipulated in the law, e.g. individuals working based on an agreement on work activity or an agreement on work performance with income lower than the specified thresholds. ${ }^{19}$ The existence of any formal legal relationship is not relevant. ${ }^{20}$ An employer is then someone who pays the employment income, when it is seated in the Czech Republic (or another state, if the participation in the Czech health insurance is derived from any international regulations).

When the current rules were introduced in 2008, large discussions had occurred, questioning the relationship between the definition of an employee and an employer for the health insurance purposes and for the personal income tax purposes, especially in case of the international hiring out of labour and employment income received from a third party.

For the international hiring out of labour structure, the official interpretation of the Ministry of Health declared the Czech entity, at which employees of a foreign company work, as an employer for the Czech health insurance purposes. As a result, any income paid or accounted by this entity was subject to the Czech health insurance contributions. On the other hand, experts declared ${ }^{21}$ that the definition of the "payer" for the personal income tax purposes must be interpreted only as the entity which actually pays out the income. This matter has not been challenged in front of a court so far and thus, the Ministry of Health keeps its interpretation.

In case of employment income received from a third party for which the employee does not perform any activity, the Ministry of Health declared that such income is not subject to the Czech health insurance contributions due to the missing activity, although many experts claim that the law does not include this limitation and thus, the health insurance contributions should be due also

19 See Section 5 letter a) of the Act No. 48/1997 Coll., Act on Public Health Insurance, as amended.

20 Until 2007, the definition of an employee was more related to the definition used for the social security purposes; the existence of a formal legal relationship was relevant by then.

21 See The Standpoint No. 141/08/ST of the Institute of State and Law of the Academy of Sciences of the Czech Republic dated 28 November 2008. 
from income paid by a third party. This matter has also not been challenged in front of a court yet.

Based on the above, income received by an employee in relation to his employment activity by another entity, for which he does not perform any activity, is not subject to the Czech health insurance contributions. Potential legal relationship between the entity which pays out the income and for which the individual works (e.g., a parent company and a subsidiary) is not relevant; the obligation to pay the health insurance contributions depends on whether the individual performs any activity for the payer of the income.

Same as in the social security area, potential recharge of the costs of the income results in a necessity for the employer to process the income in the payroll for the health insurance purposes and pay the Czech health insurance contributions.

\section{Comparison with selected states}

Since the analyzed situation is quite specific, usually without a unique arrangement in the legislation, only professionals with detail knowledge of the system are able to assess it correctly. That is why we prepared a specialized questionnaire and asked professionals in a few other countries for their expert comments. $^{22}$

The payment of the income by a third party can apply in different situations; in our analysis, we compared one specific situation, which is as follows:

An individual is employed by Company A, based on a standard employment contract. Company B, which is a parent company of Company A, provides the individual with a bonus for his employment activity performed for Company A. There is no employment relationship or any similar contract between Company $B$ and the individual. The individual works only for Company A.

We received reliable answers from the following countries: Belgium, Germany, the United Kingdom, Ireland, Hungary, the Netherlands and Russia. After the analysis described in section 2, we included also the Czech Republic.

All included countries consider income paid by Company B (the third party) as taxable income. With the exemption of Hungary, all countries also consider this income as income from dependent activity (employment income). In Russia, there is no special distinction of dependent income from the other income.

Personal income tax is paid by the employee in Germany, Hungary and Belgium. However, for Belgium it was stated that some other circumstances might be important in this particular issue. Company A is required to pay the personal

22 This method in tax research is recommended for example by Lynne, O. Ed. (2012): Taxation, a Fieldwork Research Handbook. Routledge, London, 2012. 
income tax in the United Kingdom, the Netherlands and Ireland. ${ }^{23}$ In Ireland the Company B is obliged to pay the personal income tax, if Company A did not do so. In Russia, Company B is responsible for paying the personal income tax, if it is a Russian entity; if not, the employee is obliged to do it himself. Generally, the same would apply for the Czech Republic. If Company B is seated in the Czech Republic, it should be considered a payer of the employment income, with the obligations of the tax payer. ${ }^{24}$ However, if Company B is seated outside the Czech Republic, it would in general not be considered a payer of the income and therefore, the employee would be required to declare the income in his personal income tax return and pay the tax himself.

Social security contributions (in their broader meaning including also health insurance contributions) from this income must be paid in the United Kingdom, the Netherlands and Ireland. These contributions have to be paid by Company A. In Belgium, Germany and the Czech Republic the social security contributions must be paid only if the costs of this remuneration are re-invoiced to Company A, which then pays these contributions. In Hungary a specific treatment is used for the health insurance purposes: the employee must pay the contributions himself, since there is no "employer" for this purpose.

Only in the Netherlands and the United Kingdom, the treatment of the situation would differ if the companies were unrelated. In all other countries, the relation between companies is not important.

The fact that the costs were re-invoiced by Company B to Company A is important in Belgium, the Netherlands, Hungary, Germany and the Czech Republic. If the costs of the income are re-invoiced, the social security contributions have to be paid in these countries. For the Netherlands the re-invoicing is only declaratory, since the social security contributions should be paid even if the re-invoicing does not take place (it is sufficient that Company $\mathrm{A}$ is aware of the fact that such income was provided to the employee by Company B, regardless of whether the costs were re-invoiced or not). On the other hand, re-invoicing of the income is not relevant in Ireland, Russia and the United Kingdom. However, for the United Kingdom the potential re-invoicing might be important if Company A does not have a presence in the United Kingdom.

\section{Principles behind}

The described situation - when a third party is a payer of the income from dependent activity - questions some basic principles of taxation and social security. Generally speaking, the basic principles usually work well in standard situations (in our example meaning standard relationships between an employee

23 This treatment is based on the fact that the companies A and B are related. The answer might differ if the companies were unrelated.

24 Even in this case, the employee is obliged to file a personal income tax return due to the fact that he has two employers simultaneously. 
and an employer such as a direct labour contract), however, in a bit special cases, the basic principles might fail to provide a solution which would be possible to administer in practice.

When determining the tax consequences to the specified situation, we should ask the following questions:

- What is taxable employment income?

- Should we treat tax and social security contributions differently or the same?

- How to work with the principle of assimilation of facts within EU coordination of social security?

Some of the above mentioned questions were already discussed in previous parts of the paper. Further, we point out the most important conclusions which might be further discussed. In each part we start with a brief general overview and then follow with the specific treatment in the Czech Republic.

\subsection{Taxable employment income}

Income related to employment paid by the third party is in all analyzed states taxed as employment income (income from dependent activity). Probable reason for this is that another treatment of this income would cause distortions in employment taxation and could promote tax optimization. Tax treatment of the income should depend on its source (meaning for what the income is paid) and not the way of payment which is only a technical matter.

The Czech income tax legislation considers income related to employment as income from dependent activity regardless who pays it.

However, in some situations a strict application of this rule is impractical or even absurd (e.g. little presents to employees on a cultural event organized by a third party, a tip to a waiter who is an employee of a restaurant). It is not reasonable to require payment of tax in such situations, meaning the organizer of the party or the guest of the restaurant should be considered an employer for tax purposes. The tax liability would in such cases be very low and incomparable to the related administration.

A limitation to the basic rule was suggested by the Ministry of Finance in the past, when it was confirmed by the Coordinating Committee with the Chamber of Tax Advisers that employment taxation procedure does not apply when the income is provided to the employee as a part of marketing campaign; even though the Ministry of Finance in its conclusion urges to exercise caution in tax treatment of marketing actions. ${ }^{25}$

25 See the conclusions of the negotiations of the Coordinating Committee of the Ministry of Finance and the Chamber of Tax Advisers No. 730/08.10.03. 
This forces tax professionals to seek the line between cases when the basic rule should and should not apply, without any guideline in the relevant legislation.

In the Czech Republic, also the determination of the so-called accounted income is important; as discussed in section 2.1 and deeply in the standpoint of the General Financial Directorate, expressed in the Coordinating Committee with the Chamber of Tax Advisers. ${ }^{26}$

\subsection{Tax versus social security contributions}

The obligatory contributions are very often put on par with the income tax. It is logical, as both are compulsory payments from work income. However, there are still some differences between these payments that should not be neglected. ${ }^{27}$

As discussed above, the income related to employment should be taxed as employment income, which implies that the income should be also included in the assessment base for calculation of social security contributions. However, practical realization of this straightforward idea is very problematic. Generally, for tax treatment it is only important that it is properly paid. For social security contributions, it is not only important that they are properly paid, but the payment must also be carefully ascribed to the insured person so that proper benefits can be calculated in future. To make this link between the contributions and the insured person, we must seek for the insured relationship to which the contributions can be connected.

The current Czech legislation on social security does not allow paying the contributions from the employment related income when it is paid by a third party and is not re-invoiced to the legal employer (where the connection to the insured relationship would be obvious).

With preparation of the Single Collection Point in the Czech Republic, it become more actual whether the obligatory contributions should (or could) be treated as tax. It would be most convenient for harmonization and administration to treat them in the same way, however, the specifics of the systems must be respected.

26 See the conclusions of the negotiations of the Coordinating Committee No. 393/20.02.13.

27 See also Czech national courts' rulings: 6 Ads 88/2006 - 159, 4 Ads 120/2009; Finding no. 92/1995 of the Constitutional Court, dated 12 April 1995; Finding no. Pl. ÚS 8/07 of the Constitutional Court, dated 23 March 2010; for determination of obligatory payments from employment income see for example Boháć, R. Ed. (2010): Harmonizace vyměřovacích základů daní z př́ijmů, pojistného na sociální zabezpečení a pojistného na veřejné zdravotní pojištění $\mathrm{z}$ hlediska podpory hospodářského růstu $\mathrm{v}$ České republice, in Aktuální otázky financí a finančního práva z hlediska fiskální a monetární podpory hospodářského růstu v zemích střední a východní Evropy po roce 2010. Soubor odborných statí z IX. Mezinárodní vědecké konference. Praha: Leges, 2010. 
With the common administration system for income tax and social security, it would be possible to levy the contributions in the cases when the third party is also a registered tax payer. It is true for the situations when the third party is a Czech entity. However, when the third party is not a registered tax payer, the question whether to pay the contributions is more difficult.

If the third party is not a registered tax payer and the income is not reinvoiced, the tax is paid by the employee after the end of the year in his personal income tax return. The question is: Could the social security contributions be treated the same way? Technically yes, because the employee could calculate and declare the contributions in the same form in which he declares and calculates the tax. The main complication in this case is determination of the amount of these contributions payable by the employee. The contributions are divided to a part paid by the employee and a part paid by the employer. This concept assumes that the payer of the income (the employer) would withhold the employee's part and pay his own part. However, in the mentioned case there is no "employer" which would fulfill this obligation. From a practical point of view, the registration of the third party as an employer for social security purposes would be an excessive administrative demand since the income paid in such way is often onetime or random. Also being an "employer" for social security purposes is related with significant administrative obligations linked to benefits from the social security system. The enforceability of such obligation would be difficult.

Other possibility is to let the employee pay all contributions himself. However, if only the employees' part of the contributions would be paid from such income, it would cause an undesirable distortion in costs between the income paid by a legal employer and the one paid by a third party. Further, the social security benefits would be calculated in their full amount, even if only a part of the contributions would be paid because the employers' part would be missing. This approach would lead to a conclusion that both parts of the contributions must be paid. In case the employee is required to pay both parts of the contributions from the income paid by a third party which is not a registered tax payer, it might be considered discriminatory compared to employees receiving income from their employer.

The Ministry of Finance in the above mentioned statement from the Coordinating Committee suggests a process which is not covered by any legislation. ${ }^{28}$ From the administration point of view, it would be preferred to include the income paid by a third party into the payroll of the legal employer, even if it is not re-invoiced to the employer. This conclusion has significant consequences for the social security payments. As stated above, the social security contributions should not be paid from the income paid by a third party as long as it is not reinvoiced to the legal employer. The inclusion of the income into the payroll of the

28 See the conclusions of the negotiations of the Coordinating Committee of the Ministry of Finance and the Chamber of Tax Advisers No. 730/08.10.03. 
legal employer implies that the income is accounted by the legal employer and therefore, the social security contributions should be paid. It is not appropriate to build the obligation to pay the contributions on a process which is not specifically required by any legislation. Moreover, this process assumes that the legal employer knows about the income paid by a third party; for related companies, this knowledge is highly likely, but it does not have to be the case.

\subsection{Assimilation of facts}

The assimilation of facts is an important part of basic principles of the European social security coordination and substantially influences the discussion of possible social security treatment in the situations when the employment-related income is paid by a third party.

The assimilation of facts is defined by the European Regulation on coordination of social security ${ }^{29}$ and is subject to many discussions, because the definition is not clear and its practical application is questionable..$^{30} \mathrm{~A}$ strict application of the principle of the assimilation of facts implies that all situations would be considered as if no internal borders within the states which apply the European social security coordination regulations would exist.

According to this interpretation, a third party which pays employment related income - when the third party is an entity with the seat within the states covered by the European social security coordination regulations - would have to be considered the employer for the social security purposes, since the registered seat in another state must be considered as it were in the Czech Republic. Therefore, the third party would have the obligation to register for the social security purposes in the Czech Republic and withdraw and pay the social security contributions as it were a Czech entity. ${ }^{31}$

Since the assimilation of facts is not relevant for tax purposes, the tax treatment would differ from the social security treatment in the sense that the third party from the state covered by the European social security regulations would not be considered a tax payer for the purposes of income tax, but would be considered the employer for the social security purposes.

29 Regulation (EC) No 883/2004 of the European Parliament and of the Council of 29 April 2004 on the coordination of social security systems.

30 See e.g. Pennings F. (2010): European Social Security Law. Fifth edition, Intersentia, 2010; Koldinská, K. et al. (2012): Sociální zabezpečení osob migrujících mezi státy EU. C.H.Beck, 2012; Jorens, Y. - Overmeiren, F. (2009): General Principles of Coordination in Regulation. European Journal of Social Security, 11, 2009.

31 This assumes that Czech social security system is applicable. 


\section{Conclusion}

There is not clear tax treatment of employment-related income in the Czech legislation. It might lead to complications for certain specific situations in the tax area; however, it has more significant implications in the social security area.

With the preparation of the Single Collection Point in the Czech Republic, the discussion of possible unified treatment of such situations for both tax and social security has intensified.

Currently, in the situations when the employment-related income is paid by a third party and is not re-invoiced to the legal employer, the income tax is paid, but the social security contributions (including the health insurance contributions) are not required. With the unification of the systems, the question arises whether the contributions from such income should be required as well.

Possible solutions to the unified treatment result in difficulties caused by basic differences of the systems. The unified treatment is complicated due to several reasons. Firstly, different international treaties with different basic rules apply (double tax treaties for taxation, the European Regulations and bilateral agreements for the social security). Secondly, the social security contributions must be properly linked to the insured person, so that future benefits can be calculated correctly. ${ }^{32}$

Currently, the most discussed possible treatment is that the employee would pay the social security contributions himself, when the payer of the income (a third party) would not be obliged to register as a payer for the personal income tax purposes. In such case the question of discrimination of the employee, who would bear full cost of the contributions by himself (both the employers' and the employees' part) must be argued, as well as possible impact of the principle of assimilation of facts.

These alternatives are discussed mainly in relation to the preparation of the new legislation for Single Collection Point in the Czech Republic, which should be effective from January 2015. ${ }^{33}$ Should a constructive discussion on this topic occur, its outcome might be reflected in the proposed legislation.

32 In the Czech Republic it is mainly true for pension and sickness insurance. The health insurance in the Czech Republic is closer from the economic point of view to the income tax in this context.

33 The political changes might influence the officially declared date of January 2015. 